\title{
The Overseas Experience of Audit Committee and Audit Fees: Empirical Evidence from China
}

\author{
Chengai Li $\left(\mathbb{D},{ }^{1}\right.$ Lin Pan $\mathbb{D D}^{2}$ and Meilan Chen $\mathbb{D}^{3}$ \\ ${ }^{1}$ Business School, Zhejiang Wanli University, Ningbo 315100, China \\ ${ }^{2}$ School of Economics and Management, Xiamen University of Technology, Xiamen 361024, China \\ ${ }^{3}$ School of International Business, Guangdong University of Finance \& Economics, Guangzhou 510320, China \\ Correspondence should be addressed to Meilan Chen; meilanchen@gdufe.edu.cn
}

Received 14 May 2021; Accepted 7 July 2021; Published 14 July 2021

Academic Editor: Lei Xie

Copyright (C) 2021 Chengai Li et al. This is an open access article distributed under the Creative Commons Attribution License, which permits unrestricted use, distribution, and reproduction in any medium, provided the original work is properly cited.

The complexity of audit committee experience, including the overseas experience, has an important impact on corporate governance. In this paper, we study the impact of the overseas experiences of the members of audit committee on audit fees. Our empirical analysis and results show that the audit committee overseas experience can significantly increase audit fees. Further, the positive influence of the audit committee overseas experience on audit fees is more pronounced in state-owned enterprises and regions with weak marketization. In addition, we divide the overseas experience into overseas learning experience and overseas working experience. We find that both types of experience present in the audit committee significantly increase the audit fees. Finally, we find that the audit committee overseas experience can significantly improve the quality of accounting information and play a positive role in corporate governance.

\section{Introduction}

Since the reform and opening-up, China has made remarkable progresses in its economic and social development, which are inseparable from the advanced technologies and management experience from a large number of overseas returnees. The 2018 Statistical Bulletin of Human Resources and Social Security Development issued by the Ministry of Human Resources and Social Security showed that about 3.65 million Chinese have chosen to return to China to start their careers between 1978 (the year of reform and opening-up) to the end of 2018 [1]. With more and more overseas talents returning to China, the influence of returnees on China's macroeconomy and microenterprise behavior has been studied extensively in the literature $[2,3]$.

The complex experience of executives affects their values, knowledge structure, management philosophy, and social relations, which influence the decision-making and development of enterprises [4]. Overseas experience is an important type of experience for executives. It is generally believed that returnees who have received more systematic and all-round professional education are more familiar with the latest technologies and have richer management experience, better international vision, and wider relational network $[5,6]$. China's governments have been actively developing preferential policies to attract returnees. It has been shown that returned executives can facilitate enterprise innovation [7], improve total factor productivity [8], and improve investment efficiency $[9,10]$, which reflect the knowledge accumulation effect of their overseas experience. Secondly, having studied and worked abroad for a period of time, returnees may have developed fixed ways of thinking under the influence of the overseas institutional and cultural environment. They possess ideas and perceptions relatively consistent with those in foreign countries after returning to China. For example, the existing literature has indicated that returned executives influenced by the individualism thinking of Western countries show greater awareness in risk taking and supervision $[11,12]$.

The audit committee plays a vital role in corporate governance. Specifically, it is mainly responsible for supervising financial reporting and internal control, hiring 
external audit, and bargaining the audit fees. The committee members' characteristics will affect the committee governance. Usually, the returnees have the greater governance and supervision awareness than domestic talents [4]. Will the overseas experience of an audit committee affect the demand of listed firms for the external audit and the audit fees? Currently, whether the audit committee overseas experience affects the committee governance function has not been directly studied in the literature. To address this research gap, in this paper, the governance effect of the audit committee overseas experience is studied from the perspective of audit fees. Theoretically, from the view of audit demand, the audit committee overseas experience indicates stronger awareness of audit supervision and corporate governance and relates to audit demand positively [13]. This can increase the audit fees [14]. This paper verifies the conjecture through an empirical study.

Our empirical analysis and results lead to the following major findings. First, audit committee overseas experience is significantly and positively correlated with the audit fees. Second, compared with the nonstate-owned enterprises, the state-owned ones have more pronounced positive correlation between the audit committee overseas experience and the audit fees. Third, compared with regions with high marketization degree, regions with low marketization degree have more significant positive correlation between the audit committee overseas experience and audit fees. Fourth, if the overseas experience is divided into the overseas learning experience and the overseas working experience, we find that the audit committee overseas learning experience and overseas working experience both can significantly lead to the higher audit fees. Lastly, we find that the audit committee overseas experience can significantly reduce earnings management and improve accounting information transparency.

This paper makes the following two major contributions. Firstly, the existing literature mainly focuses on the influence of the audit committee independence, financial expertise, gender composition, participation degree, and other characteristics on the governance effect of audit committee. There is a lack of research on the influence of audit committee overseas experience on the governance effect of audit committee. This paper fills this research gap. Secondly, existing studies indicate that enterprises with globalizing board and overseas experience of executives are more inclined to choose "Big 4." Different from previous studies, this paper focuses on the audit committee, a subject which can directly affect auditor choice and audit fees. Hence, our research can enrich the literature on the influencing factors of audit fees.

The remainder of this paper is organized as follows. Section 2 reviews related research. Section 3 develops our hypothesis based on theoretical analysis. Section 4 describes the basic research design, including data source, sample description, model design, and variable definition. Section 5 discusses the empirical findings from our empirical analysis and robustness test. Section 6 concludes the study and puts forward the policy insights.

\section{Literature Review}

2.1. Literature on Audit Committee Governance. The first one is the influence of the audit committee's financial expertise on the governance effect of audit committee. The Detailed Implementing Rules of the Audit Committee of the Board of Directors prepared by China Securities Regulatory Commission in 2002 pointed out that the audit committee should include at least one independent director who is an accounting professional to ensure the presence of financial and accounting expertise [15]. It is generally acknowledged that the larger the number of accounting professionals is, the stronger the financial expertise becomes in the audit committee and the better the governance effect of audit committee is. Most studies found that the audit committee's financial expertise can reduce the probability of financial restatement $[16,17]$, radical earnings management behavior [18], and internal control defects [19]. It can also increase the audit fees [20]. In addition, from the perspective of outside investors, several studies found that the capital market has a positive reaction when the audit committee hires accounting experts [21, 22], and the audit committee's accounting expertise can improve the stock liquidity and turnover [23], while the capital market will face a negative reaction when accounting experts leave the audit committee [24].

The second one is the influence of audit committee independence on the governance effect of audit committee. The Detailed Implementing Rules of the Audit Committee of the Board of Directors pointed out that the audit committee shall be formed with 3-7 directors, a majority of whom should be independent directors, so as to keep the audit committee highly independent [15]. In the absence of direct economic and emotional connection between independent directors and management, the weak supervision caused by the intimate relationship will be blocked [25]. Most of the existing studies have found that the audit committee independence can improve its governance effect. For example, in the presence of stronger audit committee independence, there will be higher earning quality [26], lower occurrence of radical earnings management [18], higher internal control quality [19], lower probability of financial restatement [16], lower probability of financial fraud [27], and higher audit fees [28-30]. The influence of the audit committee independence on the governance effect has also been studied in several studies from the view of the remuneration structure of the committee members [31-33] and the "revolving door" of the committee members [34].

The third one is the influence of the audit committee diligence on the governance effect of audit committee. Since independent directors often work in different listed companies and therefore take it as a part-time job, the committee members' diligence will affect the function of supervision. For example, several existing studies have found that the audit committee diligence is positively correlated to the audit fees [35]. And, it can reduce the probability of financial restatement [16], the radical earnings management [18], and the financial fraud [27]. 
2.2. Positive Effect of Returnees as Executives. The returning of overseas can significantly improve the economic development speed of developing countries [2]. The existing studies mainly focus on the vital function of returnees as executives and $\mathrm{CEO}$ in the enterprise development, involved in the knowledge accumulation effect and governance effect of overseas experience. As for the knowledge accumulation effect, the existing studies found that the returned executives can bring the advanced management experience and knowledge [4], which mainly come from the international vision and the management ability of returnees [3]. It facilitates the enterprise innovation input $[8,11]$ and improves the companies' total factor productivity [10] and the investment efficiency [9]. On the contrary, overseas experience can form a unique overseas social network, which can help returnees obtain more information and capital advantages [36]. In terms of the governance effect, several studies found that the overseas experience of CEO can reduce the listed companies' earnings management [12] and that the overseas experience of executives can improve the awareness of the listed companies to fulfill their social responsibilities [37], promote the internal salary gap [36], enhance the internal control quality [38], improve the corporate governance [4], and intend to choose "Big 4" for audit [39].

2.3. Our Contributions. In conclusion, the existing studies in the literature mainly focus on the influence of the audit committee characteristics on its governance effect. These characteristics include audit committee's financial expertise, audit committee independence, audit committee diligence, committee members' gender, and audit committee scale, while the governance effect includes earnings quality, internal control quality, information disclosure, and auditor choice. However, there is a lack of research on the influence of the overseas experience of an audit committee on its governance effect. Starting from the perspective of overseas experience, this paper further studies the governance effect of audit committee, so as to enrich the literature about audit committee governance. Secondly, the existing literature mainly studies the influence of individual overseas experience on the corporate behavior from the perspective of executives and CEO, while there is little research taking the audit committee as the main body to study the influence of overseas experience on the corporate governance. Therefore, this study can also enrich the literature about the influence of individual overseas experience on the corporate behavior.

\section{Theoretical Analysis and Hypothesis}

Complexity represents a state in which many factors interact [40]. The complex experiences of executives form their personal characteristics, which affect the development of enterprises. The complex experiences of executives include academic experience, political experience, professional experience, and overseas experience. There are studies on the impact of single experience on corporate governance, enterprise innovation, and enterprise performance. According to complexity theory, complex systems have the characteristics of auto-organization [41]. Executives' single experience can spontaneously form an orderly state to adapt to the environment and promote the development of enterprises. The audit committee is an integral part of the company's management, which plays an active role in supervision and governance. The overseas experience is one aspect of complex experience, which affects the governance effect of audit committee.

This paper takes audit fees as the representative of corporate governance effect. Audit fees reflect the audit supervision demand of management. The higher the demand of management audit supervision is, the higher the audit fees charge is and the better the corporate governance effect is [14]. According to the literature, the factors influencing audit fees consist of the auditee's size, the auditee's business complexity, the financial risk, the business risk, the accounting information transparency, and the corporate governance level [42-46]. According to the Rules for Governance of Listed Companies, the Detailed Implementing Rules of the Audit Committee of the Board of Directors, and the Basic Specifications for Internal Control of Enterprises $[15,47,48]$, audit committee is responsible for the selection of auditors of listed companies, and audit fees should be determined on the basis of consultation between audit committee and external auditors. Specifically, the audit committee should discuss the audit scope, audit plan, and other contents with external auditors to determine the audit fees. Therefore, the committee members' characteristics will affect the behavior of the audit committee and then the audit fees.

Based on the audit demand view, the returnees in the audit committee have stronger motivation and ability to participate in the governance, so there is higher demand for high-quality audit [13]. It is well known that the legal system in many developed countries and regions is more comprehensive, and the stricter legal system can better constrain individual behaviors, so individuals can better develop a habit of observing laws and disciplines. Secondly, different from China, many developed countries and regions have the capital markets under "strong supervision." In case of financial fraud, the listed companies and accounting firms will suffer from huge compensation and class action [49]. On the contrary, China's weak legal system, defective regulatory environment, and slight punishment may lead to prevailing financial fraud of listed companies. Based on the cognitive imprinting theory [50], returnees are more likely to maintain the ideas and behaviors formed overseas after returning to their homeland, to become more self-disciplined and otherdisciplined. Therefore, when joining the audit committee of listed companies, returnees will bring this awareness and concept to the audit committee in addition to maintaining their consistent behavioral criteria and then affect the awareness and behavior of other committee members, so as to consolidate the supervision function of the whole committee [12]. Meanwhile, having received the systematic and cutting-edge accounting and audit knowledge education abroad, these returnees will have the greater supervision ability [4]. Based on the above analysis, with higher demand for high-quality audit, audit committee is inclined to hire 
high-quality auditors and require external auditors to invest more time and energy, resulting in higher audit fees. From the analysis mentioned above, this article puts forward the following research hypothesis to be tested:

Hypothesis 1. The audit committee overseas experience is positively correlated to the audit fees.

According to the theory of property right, the property right state is an important factor influencing the corporate governance. The state-owned enterprises' property rights are ultimately attributable to all Chinese citizens. As an agent, SASAC is responsible for supervising managers of stateowned enterprises, and the unclear property rights often cause the owners' supervision absence, the stronger opportunistic motives of managers, and more serious agency problem in the state-owned enterprises [51]. The returned executives are more likely to choose the international "Big 4" firms for audit in case of relatively serious agency problem, which means that the listed companies have higher demand for high-quality audit [13]. In addition, low-quality auditors may easily compromise with state-owned enterprises. The returnees have a strong sense of the legal system and are less likely to conspire with auditors [52]. In that way, in the state-owned enterprises, in the absence of the owners' supervision, it can be reasonably expected that the audit committee overseas experience has the higher demand for high-quality audit, and this committee will require auditors to put more time and energy in work so that the audit fees are higher. Based on this, this paper puts forward the following research hypothesis to be tested.

Hypothesis 2. Compared with nonstate-owned enterprises, the audit committee overseas experience of state-owned enterprises has more significant influence on the increase of audit fees.

China is a vast country with different levels of regional economic development and institutional environment. The regions with high marketization often have more developed economy, better business climate, less government intervention, more equal judicial system, and stricter regulatory environment than those with low marketization. In the regions with higher marketization, the financial fraud of listed companies can be found and exposed more easily. Once the fraud is exposed, the management and governance layer of the listed companies will be more easily punished by the regulators [53]. Based on the cognitive imprinting theory [50], the returnees' ideas and cognition formed abroad are often entrenched and stable for a long time. Therefore, the returnees in the audit committee are less affected by the external environment of the marketization process in China. With higher demand for high-quality audit, these returnees of the audit committee will pay high attention to the corporate governance and supervision regardless of the external marketization process. Conversely, if all the members of the audit committee are domestic talents, they will be affected by the external regulatory environment easily. They actively participate in the corporate governance in the regions with higher marketization process, while they have lower motivation to participate in corporate governance in the regions with the weak marketization process. Based on the above analysis, this paper puts forward the following research hypothesis to be tested.

Hypothesis 3. Compared with the regions with the high marketization process, the positive correlation between the audit committee overseas experience and the audit fees is more significant in the regions with the weak marketization process.

\section{Study Design}

4.1. Sample Selection and Data Sources. Our sample comprises $A$-share companies listed on the Shanghai and Shenzhen Stock Exchanges from 2007 to 2018 in China. Consistent with the literature, we remove any samples with missing value. Additionally, we winsorize any quantiles with continuous variables above and below $1 \%$. As a result, 17,241 samples are obtained. The data of audit committee members come from CSMAR (CSMAR is the abbreviation of China Stock Market Accounting Research.). In order to include more samples in the empirical analysis (since several studies are based on the information of audit committee members disclosed in their resumption reports, the number of samples is reduced significantly. To minimize the sample selection problem, the information of audit committee members of the companies in the year are sorted out manually and determined based on the time of assumption of duty and the time of leaving the post of executives in CSMAR), we use the information about the appointment and departure time of audit committee members from CSMAR to judge the names of audit committee members. These names are matched with the individual characteristic data of executives in CSMAR, and the variable of audit committee overseas experience (OVERSEA) is obtained. The variable of accounting firm change (CHANGE) is obtained manually after excluding merges and renaming. The other financial indexes in this study are from CSMAR.

\subsection{Model Design and Variable Definition}

4.2.1. Model Design. To test the influence of audit committee overseas experience on audit fees, this paper sets the following model:

$$
\begin{aligned}
\text { FEES }= & \left.\beta_{0}+\beta_{1} \text { OVERSEA (OVERSEA_ratio }\right)+\beta_{2} \text { SIZE }+\beta_{3} \text { LEV }+\beta_{4} \text { ROA }+\beta_{5} \text { REC }+\beta_{6} \text { INV } \\
& +\beta_{7} \text { SHARE } 1+\beta_{8} \text { INDEP }+\beta_{9} \text { SEGMENT }+\beta_{10} \text { STATE }+\beta_{11} \text { BIG } 4+\beta_{12} \text { CHANGE }+\beta_{13} \text { OPINION }+ \text { YEAR }+ \text { IND }+\varepsilon
\end{aligned}
$$


In order to test Hypothesis 2, two interaction terms have been designed in this paper. One is the interaction term (STATE $\times$ OVERSEA) between the property right state (STATE) and the audit committee overseas experience
(OVERSEA), and the other is the interaction term (STATE $\times$ OVERSEA_ratio) between the property right state (STATE) and the audit committee overseas experience ratio (OVERSEA_ratio). The specific model is as follows:

$$
\begin{aligned}
\text { FEES }= & \beta_{0}+\beta_{1} \text { OVERSEA }(\text { OVERSEA_ratio })+\beta_{2} \text { STATE } \times \text { OVERSEA }(\text { STATE } \times \text { OVERSEA_ratio })+\beta_{3} \text { SIZE }+\beta_{4} \text { LEV }+\beta_{5} \text { ROA } \\
& +\beta_{6} \text { REC }+\beta_{7} \text { INV }+\beta_{8} \text { SHARE } 1+\beta_{9} \text { INDEP }+\beta_{10} \text { SEGMENT }+\beta_{11} \text { STATE }+\beta_{12} \text { BIG } 4+\beta_{13} \text { CHANGE }+\beta_{14} \mathrm{OPINION} \\
& + \text { YEAR }+ \text { IND }+\varepsilon .
\end{aligned}
$$

In order to test Hypothesis 3, two interaction terms have been designed in the study. One is the interaction term $($ MAR $\times$ OVERSEA) between the marketization process (MAR) and the audit committee overseas experience (OVERSEA), and the other is the interaction term
(MAR $\times$ OVERSEA_ratio) between the marketization process (MAR) and the audit committee overseas experience ratio (OVERSEA_ratio). Based on the interaction terms, this paper constructs the following model:

$$
\begin{aligned}
\text { FEES }= & \beta_{0}+\beta_{1} \text { OVERSEA }(\text { OVERSEA_ratio })+\beta_{2} \text { MAR } \times \text { OVERSEA }(\text { MAR } \times \text { OVERSEA_ratio })+\beta_{3} \text { MAR } \\
& +\beta_{4} \mathrm{SIZE}+\beta_{5} \mathrm{LEV}+\beta_{6} \mathrm{ROA}+\beta_{7} \mathrm{REC}+\beta_{8} \mathrm{INV}+\beta_{9} \mathrm{SHARE} 1+\beta_{10} \mathrm{INDEP}+\beta_{11} \mathrm{SEGMENT}+\beta_{12} \mathrm{STATE} \\
& +\beta_{13} \mathrm{BIG} 4+\beta_{14} \mathrm{CHANGE}+\beta_{15} \mathrm{OPINION}+\mathrm{YEAR}+\mathrm{IND}+\varepsilon .
\end{aligned}
$$

4.2.2. Variable Definition. The specific definitions of the variables in the models are as follows.

(1) Explained Variable. In this paper, the explained variable is the audit fees (FEES). FEES is expressed by the natural logarithm of audit fees.

(2) Explaining Variable. In this paper, the dummy and continuous variables are used to measure the audit committee overseas experience characteristic. The first variable is the audit committee overseas experience (OVERSEA). The audit committee of China's listed companies usually consists of three to seven members. If at least one of the members has overseas experience, then OVERSEA = 1; otherwise, OVER$\mathrm{SEA}=0$. The second variable is the audit committee overseas experience ratio (OVERSEA_ratio). OVERSEA_ratio means the ratio of audit committee members with overseas experience. We also consider the moderate effect of the property right state and marketization process. The property right state (STATE) is a dummy variable. When the enterprise is stateowned, STATE is 1; otherwise, STATE is 0. Wang et al. [54] published the 2017 Marketization Index of China. We use the index to measure the marketization process.

(3) Control Variable. Following the literature, the control variables in this paper include company size (SIZE), leverage (LEV), return on assets (ROA), receivables ratio (REC), inventory ratio (INV), share ratio of the largest shareholder (SHARE1), the ratio of the independent director (INDEP), the number of segments (SEGMENT), the property right state (STATE), the international big 4 firms or not (BIG4), the accounting firm change (CHANGE), audit opinion type
(OPINION), the year (YEAR), and the industry (IND). The definitions of the main variables in this paper are shown in Table 1.

\section{Empirical Results and Data Analysis}

5.1. Descriptive Statistics. The descriptive statistical results of the variables are presented in Table 2. As shown in the table, the mean of audit committee overseas experience (OVERSEA) is 0.293 , which indicates that the number of audit committee members with overseas experience accounts for $29.3 \%$ in China's A-share listed companies, and it maintains an upward trend year by year, which means that it is becoming more and more common for returnees to join the governance layer of listed companies in China. The mean of audit committee overseas experience ratio (OVERSEA_ratio) is 0.104, and the number of audit committee members with overseas experience accounts for $10.4 \%$ in average, which indicates that the audit committee overseas experience ratio is relatively low and there is still space for improvement. The maximum and minimum of the marketization process are 10.62 and 2.88, respectively, which reflect that different enterprises are in different market environments. The mean of STATE is 0.389 , which indicates that more than half of the enterprises' ultimate controllers are not state-owned. The descriptive statistical results of other variables are shown in Table 2.

5.2. Univariate Analysis. The univariate analysis results of main variables are presented in Table 3 . Based on the criterion on whether the audit committee members have overseas experience, the samples are divided into two groups, and the statistics is made on the mean and median of 
TABLE 1: Main definitions of variables.

\begin{tabular}{|c|c|c|}
\hline Variable & Symbol & Variable description \\
\hline Audit fees & FEES & Fees paid for audit service \\
\hline $\begin{array}{l}\text { Audit committee overseas } \\
\text { experience }\end{array}$ & OVERSEA & $\begin{array}{c}\text { If at least one of the members has overseas experience, OVERSEA is } 1 \text {; otherwise, } \\
\text { OVERSEA is } 0\end{array}$ \\
\hline $\begin{array}{l}\text { Audit committee overseas } \\
\text { experience ratio }\end{array}$ & OVERSEA_ratio & $\begin{array}{c}\text { Audit committee members with overseas experience/total audit committee } \\
\text { members }\end{array}$ \\
\hline Marketization process & MAR & Marketization index of China \\
\hline Property right state & STATE & $\begin{array}{c}\text { Dummy variable: STATE }=1 \text { for state-owned enterprise; STATE }=0 \text { for nonstate- } \\
\text { owned enterprise }\end{array}$ \\
\hline Company size & SIZE & Natural logarithm of total assets \\
\hline Leverage & LEV & Liabilities/total assets \\
\hline Return on assets & $\mathrm{ROA}$ & Net profit/total assets \\
\hline Receivables ratio & REC & Receivables/total assets \\
\hline Inventory ratio & INV & Inventory/total assets \\
\hline \multicolumn{3}{|l|}{ Share ratio of the largest } \\
\hline Shareholder & SHARE1 & Share ratio of the largest shareholder \\
\hline \multicolumn{3}{|l|}{ Ratio of the independent } \\
\hline Directors & INDEP & Ratio of independent directors to the total number of directors \\
\hline Number of segments & SEGMENT & Natural logarithm of the number of segments \\
\hline Big 4 & BIG4 & $\begin{array}{l}\text { If the listed company is audited by international big } 4 \text { firms, BIG } 4 \text { is } 1 \text {; otherwise, } \\
\text { BIG } 4 \text { is } 0\end{array}$ \\
\hline Auditor change & CHANGE & $\begin{array}{l}\text { Dummy variable: in case of auditor change, CHANGE is } 1 \text {; otherwise, CHANGE } \\
\text { is } 0\end{array}$ \\
\hline Audit opinion & OPINION & $\begin{array}{c}\text { Dummy variable: if the current audit opinion is modified, OPINION is } 1 \text {; } \\
\text { otherwise, OPINION is } 0\end{array}$ \\
\hline Year & YEAR & \\
\hline Industry & IND & \\
\hline
\end{tabular}

Table 2: Descriptive statistics.

\begin{tabular}{|c|c|c|c|c|c|c|}
\hline Variable & Sample size & Mean & Standard deviation & Minimum & Median & Maximum \\
\hline FEES & 17241 & 13.530 & 0.589 & 12.430 & 13.460 & 15.310 \\
\hline OVERSEA & 17241 & 0.293 & 0.455 & 0 & 0 & 1 \\
\hline OVERSEA_ratio & 17241 & 0.104 & 0.177 & 0 & 0 & 0.667 \\
\hline MAR & 17241 & 7.903 & 1.831 & 2.880 & 8.080 & 10.62 \\
\hline SIZE & 17241 & 22.040 & 1.220 & 19.470 & 21.910 & 25.630 \\
\hline LEV & 17241 & 0.445 & 0.212 & 0.055 & 0.439 & 0.943 \\
\hline ROA & 17241 & 0.038 & 0.056 & -0.201 & 0.035 & 0.196 \\
\hline REC & 17241 & 0.112 & 0.102 & 0 & 0.087 & 0.459 \\
\hline INV & 17241 & 0.157 & 0.150 & 0 & 0.117 & 0.748 \\
\hline SHARE1 & 17241 & 0.345 & 0.150 & 0.085 & 0.325 & 0.749 \\
\hline INDEP & 17241 & 0.372 & 0.052 & 0.333 & 0.333 & 0.571 \\
\hline SEGMENT & 17241 & 2.301 & 1.015 & 0 & 2.303 & 4.812 \\
\hline STATE & 17241 & 0.389 & 0.487 & 0 & 0 & 1 \\
\hline BIG4 & 17241 & 0.041 & 0.198 & 0 & 0 & 1 \\
\hline CHANGE & 17241 & 0.069 & 0.253 & 0 & 0 & 1 \\
\hline OPINION & 17241 & 0.036 & 0.187 & 0 & 0 & 1 \\
\hline
\end{tabular}

variables, respectively, for the mean test ( $T$ test) and median test $(Z$ test). As shown in Table 3 , the mean values of the audit fees in the audit committee overseas experience group (OVERSEA = 1) and the audit committee nonoverseas experience group (OVERSEA $=0)$ are 13.67 and 13.48 , respectively. The results have shown that the audit fees of the listed companies with audit committee overseas experience are significantly higher than those of the listed companies with audit committee nonoverseas experience, which preliminarily supports Hypothesis 1. In addition, the listed companies with audit committee overseas experience tend to have the larger size, the higher share ratio of the largest shareholder, the larger number of segments, the lower probability of state-owned enterprises, the higher probability of employment of international Big 4 firms, and the lower probability of nonstandard audit opinions from auditors.

5.3. Correlation Coefficient Analysis. The correlation coefficient analysis of the main variables is presented in Tables 4 and 5. It indicates that the audit committee overseas experience 
TABLE 3: Univariate analysis.

\begin{tabular}{|c|c|c|c|c|c|c|}
\hline \multirow{2}{*}{ Variable } & \multicolumn{2}{|c|}{ OVERSEA $=1$} & \multicolumn{2}{|c|}{ OVERSEA $=0$} & \multirow{2}{*}{$\begin{array}{c}\text { Mean test } \\
T \text { value }\end{array}$} & \multirow{2}{*}{$\begin{array}{c}\text { Median test } \\
Z \text { value }\end{array}$} \\
\hline & Mean & Median & Mean & Median & & \\
\hline FEES & 13.67 & 13.57 & 13.48 & 13.40 & $-20.07^{* * *}$ & $-17.39^{* * *}$ \\
\hline OVERSEA & 0 & 1 & 0 & 0 & & \\
\hline OVERSEA_ratio & 0.132 & 0.333 & 0 & 0 & & \\
\hline MAR & 8.178 & 8.640 & 7.790 & 7.880 & $-12.71^{* * *}$ & $-12.55^{* * *}$ \\
\hline SIZE & 1.342 & 23.05 & 1.157 & 22.65 & $-13.23^{* * *}$ & $-10.95^{* * *}$ \\
\hline LEV & 0.208 & 0.601 & 0.213 & 0.605 & 0.99 & 0.61 \\
\hline ROA & 0.055 & 0.066 & 0.056 & 0.063 & $-5.38^{* * *}$ & $-6.18^{* * *}$ \\
\hline REC & 0.101 & 0.168 & 0.103 & 0.167 & -0.41 & -1.03 \\
\hline INV & 0.158 & 0.196 & 0.146 & 0.199 & -0.91 & $1.88^{*}$ \\
\hline SHARE1 & 0.154 & 0.455 & 0.148 & 0.444 & $-2.51^{* *}$ & $-1.82^{*}$ \\
\hline INDEP & 0.052 & 0.400 & 0.052 & 0.429 & 0.44 & 0.26 \\
\hline SEGMENT & 1.055 & 3.135 & 0.991 & 2.890 & $-12.46^{* * *}$ & $-11.86^{* * *}$ \\
\hline STATE & 0.480 & 1 & 0.490 & 1 & $5.15^{* * *}$ & $5.15^{* * *}$ \\
\hline BIG4 & 0.271 & 0 & 0.154 & 0 & $-16.96^{* * *}$ & $-16.82^{* * *}$ \\
\hline CHANGE & 0.258 & 0 & 0.251 & 0 & -1.09 & -1.09 \\
\hline OPINION & 0.171 & 0 & 0.193 & 0 & $2.77^{* * *}$ & $2.77^{* * *}$ \\
\hline$N$ (observed value) & 5045 & 12196 & & & & \\
\hline
\end{tabular}

TABle 4: Correlation coefficients (1).

\begin{tabular}{|c|c|c|c|c|c|c|c|c|}
\hline & FEES & OVERSEA & OVERSEA_ratio & MAR & SIZE & LEV & $\mathrm{ROA}$ & REC \\
\hline FEES & 1 & & & & & & & \\
\hline OVERSEA & $0.151^{* * *}$ & 1 & & & & & & \\
\hline OVERSEA_ratio & $0.158^{* * *}$ & $0.915^{* * *}$ & 1 & & & & & \\
\hline MAR & $0.224^{* * *}$ & $0.096^{* * *}$ & $0.113^{* * *}$ & 1 & & & & \\
\hline SIZE & $0.700^{* * *}$ & $0.100^{* * *}$ & $0.097^{* * *}$ & $0.029^{* * *}$ & 1 & & & \\
\hline LEV & $0.263^{* * *}$ & -0.008 & $-0.014^{*}$ & $-0.158^{* * *}$ & $0.425^{* * *}$ & 1 & & \\
\hline $\mathrm{ROA}$ & 0.002 & $0.041^{* * *}$ & $0.045^{* * *}$ & $0.085^{* * *}$ & $0.018^{* *}$ & $-0.366^{* * *}$ & 1 & \\
\hline REC & $-0.042^{* * *}$ & 0.003 & $0.015^{* *}$ & $0.183^{* * *}$ & $-0.167^{* * *}$ & $-0.042^{* * *}$ & $0.026^{* * *}$ & 1 \\
\hline INV & $0.031^{* * *}$ & 0.007 & 0.009 & $-0.033^{* * *}$ & $0.114^{* * *}$ & $0.307^{* * *}$ & $-0.083^{* * *}$ & $-0.111^{* * *}$ \\
\hline SHARE1 & $0.097^{* * *}$ & $0.019^{* *}$ & $0.019^{* *}$ & -0.011 & $0.206^{* * *}$ & $0.045^{* * *}$ & $0.121^{* * *}$ & $-0.091^{* * *}$ \\
\hline INDEP & $0.018^{* *}$ & -0.003 & 0.008 & $0.028^{* * *}$ & -0.004 & $-0.019^{* *}$ & $-0.034^{* * *}$ & $0.025^{* * *}$ \\
\hline SEGMENT & $0.589^{* * *}$ & $0.094^{* * *}$ & $0.105^{* * *}$ & $0.142^{* * *}$ & $0.564^{* * *}$ & $0.277^{* * *}$ & 0.000 & $-0.051^{* * *}$ \\
\hline STATE & $0.059^{* * *}$ & $-0.039^{* * *}$ & $-0.057^{* * *}$ & $-0.228^{* * *}$ & $0.289^{* * *}$ & $0.266^{* * *}$ & $-0.087^{* * *}$ & $-0.198^{* * *}$ \\
\hline BIG4 & $0.332^{* * *}$ & $0.128^{* * *}$ & $0.149^{* * *}$ & $0.049^{* * *}$ & $0.266^{* * *}$ & $0.081^{* * *}$ & $0.049^{* * *}$ & $-0.064^{* * *}$ \\
\hline CHANGE & -0.011 & 0.008 & 0.006 & $-0.035^{* * *}$ & 0.009 & $0.039^{* * *}$ & $-0.038^{* * *}$ & 0.013 \\
\hline OPINION & $-0.028^{* * *}$ & $-0.021^{* * *}$ & $-0.020^{* * *}$ & $-0.050^{* * *}$ & $-0.113^{* * *}$ & $0.180^{* * *}$ & $-0.264^{* * *}$ & $-0.028^{* * *}$ \\
\hline
\end{tabular}

Note: ${ }^{* * *},{ }^{* *}$, and ${ }^{*}$ indicate significance at $0.01,0.05$, and 0.10 levels, respectively.

TABLE 5: Correlation coefficients (2).

\begin{tabular}{|c|c|c|c|c|c|c|c|c|}
\hline & INV & SHARE1 & INDEP & SEGMENT & STATE & BIG4 & CHANGE & OPINION \\
\hline INV & 1 & & & & & & & \\
\hline SHARE1 & $0.069^{* * *}$ & 1 & & & & & & \\
\hline INDEP & 0.006 & $0.021^{* * *}$ & 1 & & & & & \\
\hline SEGMENT & $0.132^{* * *}$ & 0.006 & $0.034^{* * *}$ & 1 & & & & \\
\hline STATE & $0.048^{* * *}$ & $0.214^{* * *}$ & $-0.081^{* * *}$ & $0.051^{* * *}$ & 1 & & & \\
\hline BIG4 & $-0.015^{*}$ & $0.124^{* * *}$ & 0.004 & $0.110^{* * *}$ & $0.093^{* * *}$ & 1 & & \\
\hline CHANGE & -0.006 & 0.002 & 0.002 & -0.007 & $0.042^{* * *}$ & $0.040^{* * *}$ & 1 & \\
\hline OPINION & $-0.033^{* * *}$ & $-0.091^{* * *}$ & $0.018^{* *}$ & $-0.052^{* * *}$ & $-0.029^{* * *}$ & $-0.026^{* * *}$ & $0.060^{* * *}$ & 1 \\
\hline
\end{tabular}

Note: ${ }^{* * *},{ }^{* *}$, and ${ }^{*}$ indicate significance at $0.01,0.05$, and 0.10 levels, respectively.

(OVERSEA) and the audit committee overseas experience ratio (OVERSEA) are significantly and positively correlated to the audit fees (FEES) at the level of $1 \%$. This means that the audit fees of listed companies with audit committee overseas experience is higher, and the larger the audit committee overseas experience ratio is, the higher the audit fees become. 


\subsection{Multiple Regression Analysis}

5.4.1. Audit Committee Overseas Experience and Audit Fees. The regression results of model (1) are presented in Table 6. It shows that the audit committee overseas experience (OVERSEA) and the audit committee overseas experience ratio (OVERSEA_ratio) are significantly and positively correlated to the audit fees (FEES) at the level of 1\%. This indicates that the audit committee overseas experience (OVERSEA) leads to significant increase in the audit fees when other factors are controlled. Further, the larger the audit committee overseas experience ratio (OVERSEA_ratio) is, the higher the audit fees become, which supports Hypothesis 1. As indicated, although the audit committee overseas experience can strengthen the corporate governance and reduce the audit risk faced by external auditors, the audit committee with overseas experience will have the higher demand for high-quality audit. It is more inclined to hire high-quality auditors and require them to put more time and energy in work so that the audit fees are increased. Then, the audit demand dominates. In addition, SIZE and SEGMENT are positively correlated with audit fees at the level of $1 \%$, which indicates that audit cost is an important determinant of audit fees. BIG4 is positively correlated with audit fees at the level of $1 \%$, which indicates that BIG4 charges premium fees. CHANGE is negatively correlated with audit fees at the level of $1 \%$, mainly because of low balling.

5.4.2. Audit Committee Overseas Experience, Property Right State, and Audit Fees. In this paper, we consider the moderate effect of the property right state. The study results of model (2) are presented in Table 7. As shown in the table, the interaction term (STATE $\times$ OVERSEA) and the interaction term (STATE $\times$ OVERSEA_ratio) coefficients are significantly positive at the level of $1 \%$, which means that the audit committee overseas experience of state-owned enterprises has more significant influence on the increase of audit fees than that of nonstate-owned enterprises. Hypothesis 2 is supported.

5.4.3. Marketization Process, Audit Committee Overseas Experience, and Audit Fees. In this paper, we also consider the moderate effect of the marketization process. The study results of model (3) are presented in Table 8 . As shown in the table, the interaction term $($ MAR $\times$ OVERSEA) and the interaction term (MAR $\times$ OVERSEA_ratio) coefficients are significantly negative at the level of $1 \%$, which means that the audit committee overseas experience in the regions with the low marketization process has more significant influence on the increase of audit fees than that in the regions with the high marketization process. The results support Hypothesis 3.

\subsection{Further Analysis}

5.5.1. Audit Committee Overseas Working Experience vs. Learning Experience. The overseas experience of audit committee members can be divided into the overseas
TABLE 6: Audit committee overseas experience and audit fees.

\begin{tabular}{|c|c|c|}
\hline & $\begin{array}{c}(1) \\
\text { FEES }\end{array}$ & $\begin{array}{c}(2) \\
\text { FEES }\end{array}$ \\
\hline OVERSEA & $\begin{array}{c}0.0584^{* * *} \\
(5.06)\end{array}$ & \\
\hline OVERSEA_ratio & & $\begin{array}{c}0.1519^{* * *} \\
\quad(5.03)\end{array}$ \\
\hline SIZE & $\begin{array}{c}0.2750^{* * *} \\
(35.17)\end{array}$ & $\begin{array}{c}0.2753^{* * *} \\
(35.25)\end{array}$ \\
\hline LEV & $\begin{array}{c}0.0179 \\
(0.52)\end{array}$ & $\begin{array}{c}0.0184 \\
(0.54)\end{array}$ \\
\hline ROA & $\begin{array}{c}-0.2099^{* *} \\
(-2.46)\end{array}$ & $\begin{array}{c}-0.2113^{* *} \\
(-2.48)\end{array}$ \\
\hline REC & $\begin{array}{c}0.1567^{* *} \\
(2.42)\end{array}$ & $\begin{array}{c}0.1545^{* *} \\
(2.39)\end{array}$ \\
\hline INV & $\begin{array}{c}-0.0825 \\
(-1.56)\end{array}$ & $\begin{array}{c}-0.0840 \\
(-1.59)\end{array}$ \\
\hline SHARE1 & $\begin{array}{c}-0.0068 \\
(-0.16)\end{array}$ & $\begin{array}{c}-0.0075 \\
(-0.17)\end{array}$ \\
\hline INDEP & $\begin{array}{c}-0.0835 \\
(-0.85)\end{array}$ & $\begin{array}{c}-0.0878 \\
(-0.90)\end{array}$ \\
\hline SEGMENT & $\begin{array}{c}0.0066^{* * *} \\
(15.93)\end{array}$ & $\begin{array}{c}0.0066^{* * *} \\
(15.88)\end{array}$ \\
\hline STATE & $\begin{array}{c}-0.1068^{* * *} \\
(-7.00)\end{array}$ & $\begin{array}{r}-0.1060^{* * *} \\
(-6.94)\end{array}$ \\
\hline BIG4 & $\begin{array}{c}0.5085^{* * *} \\
(13.30)\end{array}$ & $\begin{array}{c}0.5051^{* * *} \\
(13.14)\end{array}$ \\
\hline CHANGE & $\begin{array}{c}-0.0486^{* * *} \\
(-4.08)\end{array}$ & $\begin{array}{c}-0.0483^{* *} \\
(-4.06)\end{array}$ \\
\hline OPINION & $\begin{array}{c}0.1286^{* * *} \\
(5.44)\end{array}$ & $\begin{array}{c}0.1283^{* * *} \\
\quad(5.41)\end{array}$ \\
\hline YEAR & Control & Control \\
\hline IND & Control & Control \\
\hline Cons & $\begin{array}{c}7.2711^{* * * *} \\
(43.27)\end{array}$ & $\begin{array}{c}7.2676^{* * *} \\
(43.30)\end{array}$ \\
\hline$N$ & 17241 & 17241 \\
\hline$R^{2}$ adjusted & 0.610 & 0.610 \\
\hline$F$ & $173.2^{* * *}$ & $172.4^{* * *}$ \\
\hline
\end{tabular}

Note: ${ }^{* * *},{ }^{* *}$, and ${ }^{*}$ indicate significance at $0.01,0.05$, and 0.10 levels, respectively. All $t$-statistics are adjusted for robust standard errors.

working experience and the overseas learning experience. Liu [36] showed that the overseas learning experience would have larger influence on the individual values and behavior pattern than the overseas working experience. This is mainly because the overseas learning experience brings the longer and deeper western culture experience to individuals than the overseas working experience, and since the individuals in the education stage have not formed the complete values and behavior patterns, the education and culture they are exposed to during this stage can be integrated more easily by their values than those during the working stage.

Therefore, in this paper, the variable of audit committee overseas experience (OVERSEA) has been further subdivided into three variables: the audit committee overseas learning experience (OVERSEA1), the audit committee overseas working experience (OVERSEA2), and the audit committee overseas learning and working experience (OVERSEA3). The audit committee overseas learning experience (OVERSEA1) is a dummy variable, and when the audit committee member only has the overseas learning 
TABLE 7: Audit committee overseas experience, property right state, and audit fees.

\begin{tabular}{|c|c|c|}
\hline & $\begin{array}{c}(1) \\
\text { FEES }\end{array}$ & $\begin{array}{c}(2) \\
\text { FEES }\end{array}$ \\
\hline OVERSEA & $\begin{array}{c}0.0424^{* * *} \\
(5.62)\end{array}$ & \\
\hline OVERSEA $\times$ STATE & $\begin{array}{c}0.0444^{* * *} \\
(3.30)\end{array}$ & \\
\hline OVERSEA_ratio & & $\begin{array}{c}0.1270^{* * *} \\
(6.76)\end{array}$ \\
\hline OVERSEA_ratio $\times$ STATE & & $\begin{array}{c}0.0748^{* *} \\
(2.04)\end{array}$ \\
\hline SIZE & $\begin{array}{c}0.2742^{* * *} \\
(73.47)\end{array}$ & $\begin{array}{c}0.2748^{* * *} \\
(73.64)\end{array}$ \\
\hline LEV & $\begin{array}{c}0.0192 \\
(1.07)\end{array}$ & $\begin{array}{c}0.0193 \\
(1.07)\end{array}$ \\
\hline ROA & $\begin{array}{c}-0.2096^{* * *} \\
(-3.72)\end{array}$ & $\begin{array}{c}-0.2113^{* * *} \\
(-3.74)\end{array}$ \\
\hline REC & $\begin{array}{c}0.1566^{* * *} \\
(4.82)\end{array}$ & $\begin{array}{c}0.1554^{* * *} \\
(4.79)\end{array}$ \\
\hline INV & $\begin{array}{c}-0.0854^{* * *} \\
(-3.27)\end{array}$ & $\begin{array}{c}-0.0862^{* * *} \\
(-3.29)\end{array}$ \\
\hline SHARE1 & $\begin{array}{c}-0.0067 \\
(-0.33)\end{array}$ & $\begin{array}{c}-0.0073 \\
(-0.36)\end{array}$ \\
\hline INDEP & $\begin{array}{c}-0.0841 \\
(-1.59)\end{array}$ & $\begin{array}{c}-0.0884^{*} \\
(-1.67)\end{array}$ \\
\hline SEGMENT & $\begin{array}{c}0.0066^{* * *} \\
(31.44)\end{array}$ & $\begin{array}{c}0.0066^{* * * *} \\
(31.24)\end{array}$ \\
\hline STATE & $\begin{array}{c}-0.1191^{* * *} \\
(-15.84)\end{array}$ & $\begin{array}{c}-0.1131^{* * *} \\
(-15.37)\end{array}$ \\
\hline BIG4 & $\begin{array}{c}0.5060^{* * * *} \\
(28.00)\end{array}$ & $\begin{array}{c}0.5027^{* * * *} \\
(27.53)\end{array}$ \\
\hline CHANGE & $\begin{array}{c}-0.0486^{* * *} \\
(-4.04)\end{array}$ & $\begin{array}{c}-0.0482^{\text {*** }} \\
(-4.01)\end{array}$ \\
\hline OPINION & $\begin{array}{c}0.1273^{* * *} \\
(7.73)\end{array}$ & $\begin{array}{c}0.1276^{* * *} \\
(7.73)\end{array}$ \\
\hline YEAR & Control & Control \\
\hline IND & Control & Control \\
\hline Cons & $\begin{array}{c}7.2918^{* * * *} \\
(90.58)\end{array}$ & $\begin{array}{c}7.2804^{* * * *} \\
(90.47)\end{array}$ \\
\hline$N$ & 17241 & 17241 \\
\hline$R^{2}$ adjusted & 0.610 & 0.610 \\
\hline$F$ & 540.3 & 538.2 \\
\hline
\end{tabular}

Note: ${ }^{* * *},{ }^{* *}$, and ${ }^{*}$ indicate significance at $0.01,0.05$, and 0.10 levels, respectively. All $t$-statistics are adjusted for robust standard errors.

experience, OVERSEA 1 is 1 ; otherwise, OVERSEA 1 is 0 . The audit committee overseas working experience (OVERSEA2) is a dummy variable, and when the audit committee member only has the overseas working experience, OVERSEA2 is 1; otherwise, OVERSEA2 is 0 . The audit committee overseas learning and working experience (OVERSEA3) is a dummy variable, and when the audit committee member both have the overseas learning and working experience, OVERSEA3 is 1 ; otherwise, OVERSEA 3 is 0 . The audit committee overseas experience (OVERSEA) in model (1) is replaced with OVERSEA1, OVERSEA2, and OVERSEA3. The regression is made for model (1), and the results are shown in Table 9. The results indicate that the coefficients of three variables of OVERSEA1, OVERSEA2, and OVERSEA3 are significantly positive, which means that the audit committee overseas working experience and the audit committee overseas learning experience both can significantly increase the audit fees. After the $T$ test has been made to study the significant difference in the coefficients of three variables, OVERSEA1, OVERSEA2, and OVERSEA3, it has been found that there is no significant difference between OVERSEA1 and OVERSEA2. That means, in terms of the influence on the audit fees, there is no significant difference between overseas working experience and overseas learning experience, while the coefficient of OVERSEA3 is significantly greater than that of OVERSEA1 and OVERSEA2. It means that the richer the overseas experience of audit committee, the better the governance effect.

5.5.2. Economic Consequence: Earning Quality. The previous empirical studies found that the audit committee overseas experience can improve the audit committee's enthusiasm and ability to participate in corporate governance so that the external audit demand and audit fees are increased. Can the increasing demand for external audit caused by audit committee overseas experience improve the information transparency of listed companies? Based on the agent theory [55], the inconsistent interests between shareholders and management will cause the agency problems, while the shareholders' employment of external independent auditors for financial statement audit can restrain the earnings management for management supervision. As the audit committee overseas experience leads to increasing demand for external audit, the external audit will obviously play a more important role in the supervision to reduce the earnings management and improve the information transparency. On the basis of this, the correlation between the audit committee overseas experience and the earnings management (EM) (the calculation of earnings management (EM) refers to the method adopted in Dechow and Dichev [26]) has been studied in this paper. We construct model (4) for multiple linear regression, and the multiple linear regression results are shown in Table 10. The coefficients of the audit committee overseas experience (OVERSEA) and the audit committee overseas experience ratio (OVERSEA_ratio) are significantly negative at the levels of $1 \%$ and $5 \%$. The audit committee overseas experience can reduce the earnings management and improve the information transparency:

$$
\begin{aligned}
\mathrm{EM}= & \alpha_{0}+\alpha_{1} \text { OVERSEA }+\alpha_{2} \text { SIZE }+\alpha_{3} \mathrm{LEV}+\alpha_{4} \mathrm{ROA}+\alpha_{5} \mathrm{REC}+\alpha_{6} \mathrm{INV}+\alpha_{7} \mathrm{GROWTH} \\
& \alpha_{8} \text { SHARE } 1+\alpha_{9} \mathrm{INDEP}+\alpha_{10} \mathrm{STATE}+\alpha_{11} \mathrm{HOLD}+\frac{\alpha_{12} B}{M}+\alpha_{13} \mathrm{BIG} 4+\text { YEAR }+\mathrm{IND}+\varepsilon .
\end{aligned}
$$


TABLE 8: Marketization process, audit committee overseas experience, and audit fees.

\begin{tabular}{|c|c|c|}
\hline & $\begin{array}{c}(1) \\
\text { FEES }\end{array}$ & $\begin{array}{c}(2) \\
\text { FEES }\end{array}$ \\
\hline OVERSEA & $\begin{array}{c}0.2046^{* * *} \\
(7.18)\end{array}$ & \\
\hline MAR $\times$ OVERSEA & $\begin{array}{c}-0.0187^{* * *} \\
(-5.45)\end{array}$ & \\
\hline OVERSEA_ratio & & $\begin{array}{c}0.5413^{* * *} \\
(7.09)\end{array}$ \\
\hline MAR $\times$ OVERSEA_ratio & & $\begin{array}{c}-0.0491^{* * *} \\
(-5.44)\end{array}$ \\
\hline MAR & $\begin{array}{c}0.0433^{* * *} \\
(22.56)\end{array}$ & $\begin{array}{c}0.0427^{* * * *} \\
(22.66)\end{array}$ \\
\hline SIZE & $\begin{array}{c}0.2649^{* * * *} \\
(69.66)\end{array}$ & $\begin{array}{c}0.2654^{* * *} \\
(69.87)\end{array}$ \\
\hline LEV & $\begin{array}{c}0.0400^{* *} \\
(2.22)\end{array}$ & $\begin{array}{c}0.0409^{* *} \\
(2.26)\end{array}$ \\
\hline ROA & $\begin{array}{c}-0.2519^{* * *} \\
(-4.40)\end{array}$ & $\begin{array}{c}-0.2533^{* * *} \\
(-4.42)\end{array}$ \\
\hline REC & $\begin{array}{c}0.0631^{* *} \\
(1.98)\end{array}$ & $\begin{array}{c}0.0619^{*} \\
(1.94)\end{array}$ \\
\hline INV & $\begin{array}{c}-0.1032^{* * *} \\
(-3.98)\end{array}$ & $\begin{array}{c}-0.1056^{* * *} \\
(-4.07)\end{array}$ \\
\hline SHARE1 & $\begin{array}{c}-0.0175 \\
(-0.88)\end{array}$ & $\begin{array}{c}-0.0182 \\
(-0.92)\end{array}$ \\
\hline INDEP & $\begin{array}{c}-0.0540 \\
(-1.03)\end{array}$ & $\begin{array}{c}-0.0566 \\
(-1.08)\end{array}$ \\
\hline SEGMENT & $\begin{array}{c}0.1378^{* * *} \\
(37.85)\end{array}$ & $\begin{array}{c}0.1371^{* * *} \\
(37.65)\end{array}$ \\
\hline STATE & $\begin{array}{c}-0.0851^{* * *} \\
(-12.80)\end{array}$ & $\begin{array}{c}-0.0846^{* * *} \\
(-12.72)\end{array}$ \\
\hline BIG4 & $\begin{array}{c}0.5023^{* * *} \\
(28.61)\end{array}$ & $\begin{array}{c}0.4981^{* * *} \\
(28.27)\end{array}$ \\
\hline CHANGE & $\begin{array}{c}-0.0382^{* * *} \\
(-3.23)\end{array}$ & $\begin{array}{c}-0.0377^{* * *} \\
(-3.19)\end{array}$ \\
\hline OPINION & $\begin{array}{c}0.1400^{* * *} \\
(8.52)\end{array}$ & $\begin{array}{c}0.1397^{* * *} \\
(8.50)\end{array}$ \\
\hline Cons & $\begin{array}{c}6.9426^{* * * *} \\
(85.73)\end{array}$ & $\begin{array}{c}6.9393^{* * * *} \\
(85.74)\end{array}$ \\
\hline YEAR & Control & Control \\
\hline IND & Control & Control \\
\hline$N$ & 17241 & 17241 \\
\hline$R^{2}$ adjusted & 0.627 & 0.626 \\
\hline$F$ & 601.4 & 602.0 \\
\hline
\end{tabular}

Note: ${ }^{* * *},{ }^{* *}$, and ${ }^{*}$ indicate significance at $0.01,0.05$, and 0.10 levels, respectively. All $t$-statistics are adjusted for robust standard errors.

\subsection{Robustness Test}

5.6.1. Add Other Characteristic Variables of the Audit Committee. According to the literature, other characteristics of the audit committee might affect the governance ability of audit committee [16, 19, 56, 57]. Therefore, other characteristic variables of audit committee have been added into model (1) in this paper, including audit committee's gender composition (GENDER_ratio), audit committee size (ACSIZE), audit committee independence (INDEP_ratio), and the average age of audit committee members (AGE). The regression results are shown in Table 11 . The audit
TABle 9: Audit committee overseas working experience, learning experience, and audit fees.

\begin{tabular}{|c|c|}
\hline & $\begin{array}{c}(1) \\
\text { FEES }\end{array}$ \\
\hline OVERSEA1 & $\begin{array}{c}0.0540^{* *} \\
(2.49)\end{array}$ \\
\hline OVERSEA2 & $\begin{array}{c}0.0418^{* * *} \\
(2.90)\end{array}$ \\
\hline OVERSEA3 & $\begin{array}{c}0.0987^{* * *} \\
(5.63)\end{array}$ \\
\hline SIZE & $\begin{array}{c}0.2630^{* * * *} \\
(32.81)\end{array}$ \\
\hline LEV & $\begin{array}{c}0.00360 \\
(0.11)\end{array}$ \\
\hline ROA & $\begin{array}{c}-0.2133^{* *} \\
(-2.39)\end{array}$ \\
\hline REC & $\begin{array}{c}0.1269^{* *} \\
(2.00)\end{array}$ \\
\hline INV & $\begin{array}{c}-0.0838 \\
(-1.57)\end{array}$ \\
\hline SHARE1 & $\begin{array}{l}0.0102 \\
(0.24)\end{array}$ \\
\hline INDEP & $\begin{array}{c}-0.0883 \\
(-0.90)\end{array}$ \\
\hline SEGMENT & $\begin{array}{c}0.1444^{* * *} \\
(19.57)\end{array}$ \\
\hline STATE & $\begin{array}{c}-0.1036^{* * *} \\
(-6.84)\end{array}$ \\
\hline BIG4 & $\begin{array}{c}0.5189^{* * *} \\
(14.08)\end{array}$ \\
\hline CHANGE & $\begin{array}{c}-0.0461^{* * *} \\
(-3.89)\end{array}$ \\
\hline OPINION & $\begin{array}{c}0.1374^{* * *} \\
\quad(5.93)\end{array}$ \\
\hline Cons & $\begin{array}{c}7.3029^{* * * *} \\
(43.73)\end{array}$ \\
\hline YEAR & Control \\
\hline IND & Control \\
\hline$N$ & 17241 \\
\hline$R^{2}$ adjusted & 0.615 \\
\hline$F$ & 182.1 \\
\hline
\end{tabular}

committee overseas experience (OVERSEA) and the audit committee overseas experience ratio (OVERSEA_ratio) are still significantly positive at the level of $1 \%$.

5.6.2. Self-Selection. Intuitively, those listed companies with the larger size and stronger comprehensive power are more likely to attract returnees to join, and as these listed companies have the relatively perfect governance structure and higher demand for external high-quality audit, model (1) may face the self-selection problem in the verification of the correlation between the audit committee overseas experience and the audit fees. For lower influence of selfselection, two methods have been used in this paper. The first one is the propensity score match (PSM). Firstly, the company size (SIZE), the leverage (LEV), the return on 
TABLE 10: Audit committee overseas experience and earnings management.

\begin{tabular}{|c|c|c|c|c|}
\hline & $\begin{array}{l}(1) \\
\text { EM }\end{array}$ & $\begin{array}{l}(2) \\
\text { EM }\end{array}$ & $\begin{array}{l}\text { (3) } \\
\text { EM }\end{array}$ & $\begin{array}{l}(4) \\
\text { EM }\end{array}$ \\
\hline OVERSEA & $\begin{array}{c}-0.0021^{* * *} \\
(-3.15)\end{array}$ & & $\begin{array}{c}-0.0020^{* * *} \\
(-2.93)\end{array}$ & \\
\hline OVERSEA_ratio & & $\begin{array}{c}-0.0045^{* *} \\
(-2.55)\end{array}$ & & $\begin{array}{c}-0.0041^{* *} \\
(-2.31)\end{array}$ \\
\hline FEES & & & $\begin{array}{c}-0.0023^{* * *} \\
(-2.72)\end{array}$ & $\begin{array}{c}-0.0023^{* * *} \\
(-2.75)\end{array}$ \\
\hline SIZE & $\begin{array}{c}0.0016^{* * *} \\
(3.20)\end{array}$ & $\begin{array}{c}0.0016^{* * *} \\
(3.14)\end{array}$ & $\begin{array}{c}0.0024^{* * *} \\
(3.96)\end{array}$ & $\begin{array}{c}0.0024^{* * *} \\
(3.93)\end{array}$ \\
\hline LEV & $\begin{array}{c}0.0123^{* * *} \\
(4.41)\end{array}$ & $\begin{array}{c}0.0123^{* * *} \\
(4.41)\end{array}$ & $\begin{array}{c}0.0125^{* * *} \\
(4.47)\end{array}$ & $\begin{array}{c}0.0125^{* * *} \\
(4.48)\end{array}$ \\
\hline $\mathrm{ROA}$ & $\begin{array}{c}0.5835^{* * *} \\
(58.17)\end{array}$ & $\begin{array}{c}0.5835^{* * *} \\
(58.18)\end{array}$ & $\begin{array}{c}0.5825^{* * *} \\
(57.95)\end{array}$ & $\begin{array}{c}0.5825^{* * *} \\
(57.96)\end{array}$ \\
\hline REC & $\begin{array}{c}0.0222^{* * *} \\
(5.67)\end{array}$ & $\begin{array}{c}0.0223^{* * *} \\
(5.68)\end{array}$ & $\begin{array}{c}0.0227^{* * *} \\
(5.76)\end{array}$ & $\begin{array}{c}0.0227^{* * *} \\
(5.78)\end{array}$ \\
\hline INV & $\begin{array}{c}0.0056 \\
(1.59)\end{array}$ & $\begin{array}{c}0.0057 \\
(1.61)\end{array}$ & $\begin{array}{c}0.0055 \\
(1.55)\end{array}$ & $\begin{array}{c}0.0055 \\
(1.56)\end{array}$ \\
\hline GROWTH & $\begin{array}{c}-0.0006^{* *} \\
(-2.12)\end{array}$ & $\begin{array}{c}-0.0006^{* *} \\
(-2.12)\end{array}$ & $\begin{array}{c}-0.0007^{* *} \\
(-2.16)\end{array}$ & $\begin{array}{c}-0.0007^{* *} \\
(-2.16)\end{array}$ \\
\hline SHARE1 & $\begin{array}{c}-0.0014 \\
(-0.63)\end{array}$ & $\begin{array}{c}-0.0014 \\
(-0.64)\end{array}$ & $\begin{array}{c}-0.0016 \\
(-0.69)\end{array}$ & $\begin{array}{c}-0.0016 \\
(-0.69)\end{array}$ \\
\hline INDEP & $\begin{array}{c}-0.0075 \\
(-1.26)\end{array}$ & $\begin{array}{c}-0.0073 \\
(-1.23)\end{array}$ & $\begin{array}{c}-0.0076 \\
(-1.29)\end{array}$ & $\begin{array}{c}-0.0075 \\
(-1.26)\end{array}$ \\
\hline STATE & $\begin{array}{c}-0.0023^{* * *} \\
(-2.92)\end{array}$ & $\begin{array}{c}-0.0023^{* * *} \\
(-2.92)\end{array}$ & $\begin{array}{c}-0.0026^{* * *} \\
(-3.26)\end{array}$ & $\begin{array}{c}-0.0026^{* * *} \\
(-3.26)\end{array}$ \\
\hline HOLD & $\begin{array}{c}-0.0038^{*} \\
(-1.89)\end{array}$ & $\begin{array}{c}-0.0038^{*} \\
(-1.87)\end{array}$ & $\begin{array}{c}-0.0037^{*} \\
(-1.84)\end{array}$ & $\begin{array}{c}-0.0037^{*} \\
(-1.83)\end{array}$ \\
\hline $\mathrm{B} / \mathrm{M}$ & $\begin{array}{c}0.0086^{* * * *} \\
(4.06)\end{array}$ & $\begin{array}{c}0.0087^{* * * *} \\
(4.08)\end{array}$ & $\begin{array}{c}0.0081^{* * * *} \\
(3.82)\end{array}$ & $\begin{array}{c}0.0082^{* * * *} \\
(3.84)\end{array}$ \\
\hline BIG4 & $\begin{array}{c}-0.0045^{* * *} \\
(-2.83)\end{array}$ & $\begin{array}{c}-0.0046^{* * *} \\
(-2.83)\end{array}$ & $\begin{array}{c}-0.0034^{* *} \\
(-2.10)\end{array}$ & $\begin{array}{c}-0.0034^{* *} \\
(-2.10)\end{array}$ \\
\hline Cons & $\begin{array}{c}-0.0502^{* * *} \\
(-5.09)\end{array}$ & $\begin{array}{c}-0.0499^{* * *} \\
(-5.05)\end{array}$ & $\begin{array}{c}-0.0372^{* * *} \\
(-3.56)\end{array}$ & $\begin{array}{c}-0.0367^{* * *} \\
(-3.51)\end{array}$ \\
\hline YEAR & Control & Control & Control & Control \\
\hline IND & Control & Control & Control & Control \\
\hline$N$ & 13433 & 13433 & 13433 & 13433 \\
\hline$R^{2}$ adjusted & 0.405 & 0.404 & 0.405 & 0.405 \\
\hline$F$ & 143.9 & 143.8 & 140.6 & 140.5 \\
\hline
\end{tabular}

Note: ${ }^{* * *},{ }^{* *}$, and ${ }^{*}$ indicate significance at $0.01,0.05$, and 0.10 levels, respectively. All $t$-statistics are adjusted for robust standard errors.

TABLE 11: Other characteristic variables of the audit committee.

\begin{tabular}{|c|c|c|}
\hline & $\begin{array}{c}(1) \\
\text { FEES }\end{array}$ & $\begin{array}{c}(2) \\
\text { FEES }\end{array}$ \\
\hline OVERSEA & $\begin{array}{c}0.0639^{* * *} \\
(5.54)\end{array}$ & \\
\hline OVERSEA_ratio & & $\begin{array}{c}0.1639^{* * *} \\
\quad(5.51)\end{array}$ \\
\hline SIZE & $\begin{array}{c}0.2620^{* * * *} \\
(32.37)\end{array}$ & $\begin{array}{c}0.2622^{* * * *} \\
(32.44)\end{array}$ \\
\hline LEV & $\begin{array}{c}0.0054 \\
(0.16)\end{array}$ & $\begin{array}{c}0.0055 \\
(0.16)\end{array}$ \\
\hline ROA & $\begin{array}{c}-0.2189^{* *} \\
(-2.46)\end{array}$ & $\begin{array}{c}-0.2199^{* *} \\
(-2.46)\end{array}$ \\
\hline REC & $\begin{array}{c}0.1268^{* *} \\
(2.00)\end{array}$ & $\begin{array}{c}0.1256^{* *} \\
(1.98)\end{array}$ \\
\hline INV & $\begin{array}{c}-0.0847 \\
(-1.60)\end{array}$ & $\begin{array}{c}-0.0858 \\
(-1.62)\end{array}$ \\
\hline SHARE1 & 0.0085 & 0.0086 \\
\hline
\end{tabular}


TABle 11: Continued.

\begin{tabular}{|c|c|c|}
\hline & $\begin{array}{c}(1) \\
\text { FEES }\end{array}$ & $\begin{array}{c}(2) \\
\text { FEES }\end{array}$ \\
\hline & $(0.20)$ & $(0.20)$ \\
\hline INDEP & $\begin{array}{c}-0.0828 \\
(-0.84)\end{array}$ & $\begin{array}{c}-0.0840 \\
(-0.85)\end{array}$ \\
\hline SEGMENT & $\begin{array}{c}0.1446^{* * *} \\
(19.60)\end{array}$ & $\begin{array}{c}0.1442^{* * *} \\
(19.54)\end{array}$ \\
\hline STATE & $\begin{array}{c}-0.1061^{* * *} \\
(-6.95)\end{array}$ & $\begin{array}{c}-0.1062^{* * *} \\
(-6.95)\end{array}$ \\
\hline BIG4 & $\begin{array}{c}0.5216^{* * *} \\
(14.16)\end{array}$ & $\begin{array}{c}0.5179^{* * *} \\
(13.97)\end{array}$ \\
\hline CHANGE & $\begin{array}{c}-0.0461^{* * *} \\
(-3.90)\end{array}$ & $\begin{array}{c}-0.0459^{* * *} \\
(-3.89)\end{array}$ \\
\hline OPINION & $\begin{array}{c}0.1390^{* * * *} \\
(6.04)\end{array}$ & $\begin{array}{c}0.1388^{* * *} \\
(6.02)\end{array}$ \\
\hline ACSIZE & $\begin{array}{c}-0.0065 \\
(-0.65)\end{array}$ & $\begin{array}{c}-0.0026 \\
(-0.27)\end{array}$ \\
\hline AGE & $\begin{array}{c}0.0027^{* *} \\
(2.42)\end{array}$ & $\begin{array}{c}0.0027^{* *} \\
(2.42)\end{array}$ \\
\hline INDEP_ratio & $\begin{array}{c}-0.0643 \\
(-0.86)\end{array}$ & $\begin{array}{c}-0.0725 \\
(-0.98)\end{array}$ \\
\hline GENDER_ratio & $\begin{array}{c}-0.0025 \\
(-0.10)\end{array}$ & $\begin{array}{c}-0.0005 \\
(-0.02)\end{array}$ \\
\hline Cons & $\begin{array}{c}7.2581^{* * *} \\
(40.93)\end{array}$ & $\begin{array}{c}7.2491^{* * *} \\
(40.91)\end{array}$ \\
\hline YEAR & Control & Control \\
\hline IND & Control & Control \\
\hline$N$ & 17241 & 17241 \\
\hline$R^{2}$ adjusted & 0.615 & 0.615 \\
\hline$F$ & 173.8 & 173.3 \\
\hline
\end{tabular}

Note: ${ }^{* * *},{ }^{* *}$, and ${ }^{*}$ indicate significance at $0.01,0.05$, and 0.10 levels, respectively. All $t$-statistics are adjusted for robust standard errors.

TABLE 12: Propensity score match.

\begin{tabular}{|c|c|c|}
\hline & $\begin{array}{c}(1) \\
\text { FEES }\end{array}$ & $\begin{array}{c}(2) \\
\text { FEES }\end{array}$ \\
\hline OVERSEA & $\begin{array}{c}0.0598^{* * *} \\
(7.17)\end{array}$ & \\
\hline OVERSEA_ratio & & $\begin{array}{c}0.1528^{* * *} \\
(7.45)\end{array}$ \\
\hline SIZE & $\begin{array}{c}0.2807^{* * *} \\
(51.74)\end{array}$ & $\begin{array}{c}0.2810^{* * *} \\
(51.85)\end{array}$ \\
\hline LEV & $\begin{array}{l}0.0061 \\
(0.23)\end{array}$ & $\begin{array}{c}0.0089 \\
(0.33)\end{array}$ \\
\hline ROA & $\begin{array}{c}-0.2833^{* * *} \\
(-3.24)\end{array}$ & $\begin{array}{c}-0.2873^{* * *} \\
(-3.27)\end{array}$ \\
\hline REC & $\begin{array}{c}0.0575 \\
(1.27)\end{array}$ & $\begin{array}{c}0.0534 \\
(1.18)\end{array}$ \\
\hline INV & $\begin{array}{c}-0.0514 \\
(-1.30)\end{array}$ & $\begin{array}{c}-0.0556 \\
(-1.40)\end{array}$ \\
\hline SHARE1 & $\begin{array}{c}-0.0489^{*} \\
(-1.70)\end{array}$ & $\begin{array}{c}-0.0509^{*} \\
(-1.77)\end{array}$ \\
\hline INDEP & $\begin{array}{c}-0.0811 \\
(-1.04)\end{array}$ & $\begin{array}{c}-0.0893 \\
(-1.15)\end{array}$ \\
\hline SEGMENT & $\begin{array}{c}0.1402^{* * *} \\
(26.19)\end{array}$ & $\begin{array}{c}0.1392^{* * *} \\
(25.98)\end{array}$ \\
\hline STATE & $\begin{array}{c}-0.0975^{* * *} \\
(-9.84)\end{array}$ & $\begin{array}{c}-0.0954^{* * *} \\
(-9.62)\end{array}$ \\
\hline BIG4 & $\begin{array}{c}0.5196^{* * * *} \\
(25.54)\end{array}$ & $\begin{array}{c}0.5144^{* * *} \\
(25.10)\end{array}$ \\
\hline
\end{tabular}


TABLE 12: Continued.

\begin{tabular}{|c|c|c|}
\hline & $\begin{array}{c}(1) \\
\text { FEES }\end{array}$ & $\begin{array}{c}(2) \\
\text { FEES }\end{array}$ \\
\hline CHANGE & $\begin{array}{c}-0.0420^{* *} \\
(-2.46)\end{array}$ & $\begin{array}{c}-0.0416^{* *} \\
(-2.44)\end{array}$ \\
\hline OPINION & $\begin{array}{c}0.1259^{* * *} \\
\quad(5.07)\end{array}$ & $\begin{array}{c}0.1248^{* * *} \\
\quad(5.01)\end{array}$ \\
\hline Cons & $\begin{array}{c}6.9468^{* * *} \\
(61.44)\end{array}$ & $\begin{array}{c}6.9492^{* * *} \\
(61.51)\end{array}$ \\
\hline YEAR & Control & Control \\
\hline IND & Control & Control \\
\hline$N$ & 8490 & 8490 \\
\hline$R^{2}$ adjusted & 0.643 & 0.643 \\
\hline$F$ & 369.8 & 369.2 \\
\hline
\end{tabular}

Note: ${ }^{* * *},{ }^{* *}$, and ${ }^{*}$ indicate significance at $0.01,0.05$, and 0.10 levels, respectively. All $t$-statistics are adjusted for robust standard errors.

TABle 13: Two-stage procedure.

\begin{tabular}{|c|c|c|}
\hline & $\begin{array}{c}\text { (1) } \\
\text { The first stage } \\
\text { OVERSEA }\end{array}$ & $\begin{array}{l}(2) \\
\text { The second stage } \\
\text { FEES }\end{array}$ \\
\hline OVERSEA & & $\begin{array}{c}0.3126^{*} \\
(1.85)\end{array}$ \\
\hline SIZE & $\begin{array}{c}0.0861^{* * *} \\
(6.52)\end{array}$ & $\begin{array}{c}0.2559^{* * *} \\
(41.40)\end{array}$ \\
\hline LEV & $\begin{array}{c}-0.2700^{* * *} \\
(-3.97)\end{array}$ & $\begin{array}{l}0.0223 \\
(0.97)\end{array}$ \\
\hline ROA & $\begin{array}{l}0.290 \\
(1.33)\end{array}$ & $\begin{array}{c}-0.2390^{* * *} \\
(-4.01)\end{array}$ \\
\hline REC & $\begin{array}{c}0.0270 \\
(0.23)\end{array}$ & $\begin{array}{c}0.1262^{* * *} \\
(3.93)\end{array}$ \\
\hline INV & $\begin{array}{c}-0.0881 \\
(-0.93)\end{array}$ & $\begin{array}{c}-0.0754^{* * *} \\
(-2.86)\end{array}$ \\
\hline SHARE1 & $\begin{array}{l}0.114 \\
(1.56)\end{array}$ & $\begin{array}{c}0.00160 \\
(0.07)\end{array}$ \\
\hline INDEP & $\begin{array}{l}-0.329 \\
(-1.63)\end{array}$ & $\begin{array}{c}-0.0584 \\
(-1.04)\end{array}$ \\
\hline SEGMENT & $\begin{array}{c}0.0740^{* * *} \\
(5.58)\end{array}$ & $\begin{array}{c}0.1386^{* * *} \\
(25.24)\end{array}$ \\
\hline STATE & $\begin{array}{c}-0.1500^{* * *} \\
(-6.18)\end{array}$ & $\begin{array}{c}-0.0920^{* * * *} \\
(-8.80)\end{array}$ \\
\hline BIG4 & $\begin{array}{c}0.6366^{* * *} \\
(12.28)\end{array}$ & $\begin{array}{c}0.4631^{* * *} \\
(10.12)\end{array}$ \\
\hline CHANGE & $\begin{array}{c}0.0427 \\
(1.05)\end{array}$ & $\begin{array}{c}-0.0499^{* * *} \\
(-4.09)\end{array}$ \\
\hline OPINION & $\begin{array}{l}0.0317 \\
(0.52)\end{array}$ & $\begin{array}{c}0.1357^{* * *} \\
(8.27)\end{array}$ \\
\hline IMR & & $\begin{array}{l}-0.150 \\
(-1.49)\end{array}$ \\
\hline Cons & $\begin{array}{c}-2.6031^{* * *} \\
(-9.16)\end{array}$ & $\begin{array}{c}7.3970^{* * *} \\
(71.47)\end{array}$ \\
\hline YEAR & Control & Control \\
\hline IND & Control & Control \\
\hline$N$ & 17241 & 17241 \\
\hline$R^{2}$ adjusted & 0.036 & 0.615 \\
\hline Wald $\mathrm{chi}^{2} / F$ & 703.59 & 591.2 \\
\hline
\end{tabular}

Note: ${ }^{* * *},{ }^{* *}$, and ${ }^{*}$ indicate significance at $0.01,0.05$, and 0.10 levels, respectively. All $t$-statistics are adjusted for robust standard errors.

assets (ROA), the property right state (STATE), and the $\mathrm{BH}$ share (BHSHARE) are selected as the matching variables for the nearest neighbour matching. Upon the matching, in case of no significant difference between the treatment group and the control group, the parallel hypothesis is met. Secondly, all unmatched samples are removed, and new samples are used for model (1) regression, while the results are shown in Table 12. The audit committee overseas experience (OVERSEA) and the audit committee overseas experience ratio (OVERSEA_ratio) are still significantly positive at the level of $1 \%$. The second one is the Heckman two-stage procedure (2SLS). In the first stage, the audit committee overseas experience (OVERSEA) is used as the dependent variable, and the control variable in model (1) is taken as the independent variable for multiple linear regression. The inverse Mills ratio (IMR) is calculated in the first stage. In the second stage, the inverse Mills ratio (IMR) is placed into model (1) for regression, and the results are shown in Table 13. The coefficient of audit committee overseas experience (OVERSEA) is still significantly positive at the level of $1 \%$.

\section{Conclusions and Managerial and Policy Insights}

The governance role of audit committee has always been a topic of public concern for academics, practitioners, and regulators. Unlike previous research on committee members' accounting expertise, independence, enthusiasm, and other characteristics, this paper focuses on the influence of the audit committee overseas experience on the audit fees. The major findings of this paper include the following. First, the audit committee overseas experience can significantly increase the audit fees. Second, the audit committee overseas experience can also improve the demand of listed companies for external audit. Third, the audit committee overseas experience has more pronounced positive effect on the audit fees in state-owned enterprises, which indicates that the audit committee members with overseas experience have higher demand for external audit in case of relatively serious agency. Fourth, the audit committee overseas experience has more significant positive effect on the audit fees in the regions with the weak marketization process. It means that the returnees can maintain their consistent cognition and behavior with those in foreign countries in regions with both 
high and low marketization, which supports the cognitive imprinting theory. Fifth, in this paper, the overseas experience is divided into overseas learning experience and overseas working experience. The results show that both experience types can significantly increase audit fees. Finally, the governance role of the audit committee overseas experience is analyzed from the perspective of accounting information quality in this paper. The results indicate that the audit committee overseas experience can improve earnings quality.

The conclusions obtained through this research lead to the following insights. The audit committee is an important part of the corporate governance mechanism. This research indicates that the corporate governance and information transparency can be strengthened and improved under the audit committee with overseas returnees. The higher the audit committee overseas experience ratio is, the better the governance effect of audit committee becomes. Therefore, the listed companies should attach importance to attract overseas returnees. Especially, those with poor corporate governance and more serious agency problems should focus on hiring this returnee to improve their corporate governance. Finally, our research results can also guide investors in the capital market. The governance of listed companies with overseas returnees can often improve the earnings quality and the information transparency, so the investors should take the corporate governance factors into account during their decision-making [58-61].

\section{Data Availability}

The data used to support the findings of this study are available from the corresponding author upon request.

\section{Conflicts of Interest}

The authors declare that there are no conflicts of interest regarding the publication of this paper.

\section{Acknowledgments}

This research was funded by the Zhejiang Social Science Fund (20NDJC164YB), Zhejiang Public Projects (LGF20G030003), and Zhejiang Provincial Natural Science Foundation of China (LY20G020006 and LQ19G030007).

\section{References}

[1] Ministry of Human Resources and Social Security (MHRSS), "The 2018 statistical bulletin of human resources and social security development," MHRSS Release No. 2018-12, MHRSS, Beijing, China, 2018, http://www.mohrss.gov.cn/SYrlzyhshbzb/ zwgk/szrs/tjgb/201906/t20190611_320429.html.

[2] A. Saxenian, "From brain drain to brain circulation: transnational communities and regional upgrading in India and China," Studies in Comparative International Development, vol. 40, no. 2, pp. 35-61, 2005.

[3] H. Li, Y. Zhang, Y. Li, L.-A. Zhou, and W. Zhang, "Returnees versus locals: who perform better in China's technology entrepreneurship?" Strategic Entrepreneurship Journal, vol. 6, no. 3, pp. 257-272, 2012.
[4] M. Giannetti, G. Liao, and X. Yu, "The brain gain of corporate boards: evidence from China," The Journal of Finance, vol. 70, no. 4, pp. 1629-1682, 2015.

[5] R. Yuan and W. Wen, "Managerial foreign experience and corporate innovation," Journal of Corporate Finance, vol. 48, pp. 752-770, 2018.

[6] C. Z. Wu, "Executive summary," ECE Environmental Performance Reviews Series, vol. 10, pp. 23-30, 2019.

[7] Z. J. Zhou, Y. P. Li, and Q. Hu, "Returnee executives and innovation investment: the moderating role of managerial ownership-evidence from China's GEM companies," Social Sciences of Beijing, vol. 3, pp. 41-51, 2014.

[8] M. Q. Sheng, S. Z. Jiang, and A. Q. Sheng, "Executives overseas experience and corporate total factor productivity," The Theory and Practice of Finance and Economics, vol. 40, no. 3, pp. 141-147, 2019.

[9] M. Qi, "Green credit, financial ecological environment, and investment efficiency," Complexity, vol. 2021, Article ID 5539195, 14 pages, 2021.

[10] L. X. Liu and X. L. Zhan, "Analysis of financing efficiency of Chinese agricultural listed companies based on machine learning," Complexity, vol. 2019, Article ID 9190273, 11 pages, 2019.

[11] J. B. Song, W. Wen, and D. H. Wang, "Can returnee managers promote corporate risk: taking evidence from Chinese a share companies," Finance Trade Economics, vol. 38, no. 12, pp. 111-126, 2017.

[12] Y. Du, 'CEO' s overseas experience and earnings management," Accounting Research, vol. 2, pp. 27-33, 2018.

[13] Z. J. Zhou and S. C. Song, "Returnee executives and auditor choice: the role of agency cost," Journal of Audit and Economics, vol. 3, pp. 42-51, 2019.

[14] C. H. David, W. R. Knechel, and N. Wong, "Audit fees: a meta-analysis of the effect of supply and demand attributes," Contemporary Accounting Research, vol. 23, no. 1, pp. 141-191, 2006.

[15] China Securities Regulatory Commission (CSRC), “The detailed implementing rules of the audit committee of the board of directors," CSRC Release No. 2002-35, CSRC, Beijing, China, 2002, http://app.news.esnai.com/? controller $=$ esnai\&action $=$ wapnewcontent $\&$ cid $=2835$.

[16] L. J. Abbott, S. Parker, and G. F. Peters, "Audit committee characteristics and restatements," AUDITING: A Journal of Practice \& Theory, vol. 23, no. 1, pp. 69-87, 2004.

[17] S. H. Wang, W. Xu, and Z. Q. Liu, "Executive power, audit committee's financial expertise and financial restatement," Auditing Research, vol. 3, pp. 101-110, 2019.

[18] J. Bédard, S. M. Chtourou, and L. Courteau, "The effect of audit committee expertise, independence, and activity on aggressive earnings management," Auditing A Journal of Practice \& Theory, vol. 23, no. 2, pp. 13-35, 2004.

[19] J. Krishnan, "Audit committee quality and internal control: an empirical analysis," The Accounting Review, vol. 80, no. 2, pp. 649-675, 2005.

[20] G. Krishnan and G. Visvanathan, "Do auditors price audit committee's expertise? The case of accounting versus nonaccounting financial experts," Journal of Accounting, Auditing \& Finance, vol. 24, no. 1, pp. 115-144, 2009.

[21] W. N. Davidson, B. Xie, and W. Xu, "Market reaction to voluntary announcements of audit committee appointments: the effect of financial expertise," Journal of Accounting and Public Policy, vol. 23, no. 4, pp. 279-293, 2004.

[22] M. L. Defond, R. N. Hann, and X. Hu, "Does the market value financial expertise on audit committees of boards of 
directors?" Journal of Accounting Research, vol. 43, no. 2, pp. 153-193, 2005.

[23] D. B. Farber, S. X. Huang, and E. Mauldin, "Audit committee accounting expertise, analyst following, and market liquidity," Journal of Accounting, Auditing \& Finance, vol. 33, no. 2, pp. 174-199, 2018.

[24] M. Singhvi, D. V. Rama, and A. Barua, "Market reactions to departures of audit committee directors," Accounting Horizons, vol. 27, no. 1, pp. 113-128, 2013.

[25] J. V. Carcello and T. L. Neal, "Audit committee characteristics and auditor reporting," The Accounting Review, vol. 75, no. 4, pp. 453-467, 1998.

[26] P. M. Dechow and I. D. Dichev, "The quality of accruals and earnings: the role of accrual estimation errors," The Accounting Review, vol. 77, no. s-1, pp. 35-59, 2002.

[27] M. S. Beasley, "An empirical analysis of the relation between the board of director composition and financial statement fraud," The Accounting Review, vol. 71, no. 4, pp. 443-465, 1996.

[28] S. Mitra, M. Hossain, and D. R. Deis, "The empirical relationship between ownership characteristics and audit fees," Review of Quantitative Finance and Accounting, vol. 28, no. 3, pp. 257-285, 2007.

[29] N. Vafeas and J. F. Waegelein, "The association between audit committees, compensation incentives, and corporate audit fees," Review of Quantitative Finance and Accounting, vol. 28, no. 3, pp. 241-255, 2007.

[30] L. Loukil, "Audit committees and audit fees: an empirical study in large French listed companies," Journal of Accounting Business \& Management, vol. 21, no. 2, pp. 36-53, 2014.

[31] L. J. Lynch and S. P. Williams, "Does equity compensation compromise audit committee independence? Evidence from earnings management," Journal of Managerial Issues, vol. 24, no. 3, pp. 293-320, 2012.

[32] M. B. Keune and K. M. Johnstone, "Audit committee incentives and the resolution of detected misstatements," AUDITING: A Journal of Practice \& Theory, vol. 34, no. 4, pp. 109-137, 2015.

[33] J. L. Campbell, J. Hansen, C. A. Simon, and J. L. Smith, “Audit committee stock options and financial reporting quality after the Sarbanes-Oxley act of 2002," AUDITING: A Journal of Practice \& Theory, vol. 34, no. 2, pp. 91-120, 2015.

[34] B. E. Christensen, T. C. Omer, M. K. Shelley, and P. A. Wong, "Affiliated former partners on the audit committee: influence on the auditor-client relationship and audit quality," AUDITING: A Journal of Practice \& Theory, vol. 38, no. 3, pp. 95-119, 2019.

[35] L. Zhou, "Audit committee characteristics and audit fee," The Theory and Practice of Finance and Economics, vol. 31, no. 3, pp. 87-92, 2010.

[36] G. Q. Liu and G. W. Kong, "Does the overseas experience of executives increase the pay gap?" Journal of Management World, vol. 34, no. 8, pp. 130-142, 2018.

[37] D. J. Slater and H. R. Dixon-Fowler, "CEO international assignment experience and corporate social performance," Journal of Business Ethics, vol. 89, no. 3, pp. 473-489, 2009.

[38] Z. J. Zhou, B. G. Hu, and T. Zhuang, "Returnee audit committee and internal control quality," Auditing Research, vol. 6, pp. 114-121, 2020.

[39] X. Q. Du and X. Tan, "The globalizing board, analyst coverage and cash dividend," Journal of Financial Research, vol. 8, pp. 192-206, 2017.

[40] G. Zhang, W. J. Wang, and Y. K. Liang, "Understanding the complex adoption behavior of cloud services by SMEs based on complexity theory: a fuzzy sets qualitative comparative analysis (fsQCA)," Complexity, vol. 2021, Article ID 5591446, 17 pages, 2021.

[41] M. Edgar, La Méthode 6: Ethique, Editions du Seuil, Paris, France, 2004.

[42] D. Simunic, "The pricing of audit services-theory and evidence," Journal of Accounting Research, vol. 18, pp. 183-226, 1980.

[43] T. B. Bell, W. R. Landsman, and D. A. Shackelford, "Auditors' perceived business risk and audit fees: analysis and evidence," Journal of Accounting Research, vol. 39, no. 1, pp. 35-43, 2010.

[44] J. D. Lyon and M. W. Maher, "The importance of business risk in setting audit fees: evidence from cases of client misconduct," Journal of Accounting Research, vol. 43, no. 1, pp. 133-151, 2005.

[45] C. E. Hogan and M. S. Wilkins, "Evidence on the audit risk model: do auditors increase audit fees in the presence of internal control deficiencies?" Contemporary Accounting Research, vol. 25, no. 1, pp. 219-242, 2010.

[46] X. Liu, G. J. Lobo, and H. C. Yu, "Is audit committee equity compensation related to audit fees?" Contemporary Accounting Research, vol. 38, no. 1, pp. 740-769, 2020.

[47] China Securities Regulatory Commission (CSRC), "Governance standards of listed companies," CSRC Release No. 201829, CSRC, Beijing, China, 2018, http://www.csrc.gov.cn/pub/ zjhpublic/zjh/201809/t20180930_344906.htm.

[48] China Securities Regulatory Commission (CSRC), "The basic specifications for internal control of enterprises," CSRC Release No. 2014-17, CSRC, Beijing, China, 2014, http://www.csrc.gov.cn/pub/shenzhen/xxfw/tzzsyd/ssgs/ sszl/ssgsxx/201403/t20140317_245540.htm.

[49] T. C. Martins and W. Novaes, "Mandatory dividend rules: do they make it harder for firms to invest?" Journal of Corporate Finance, vol. 18, no. 4, pp. 953-967, 2012.

[50] C. Marquis and A. Tilcsik, "Imprinting: toward a multilevel theory," Academy of Management Annals, vol. 7, no. 1, pp. 195-245, 2013.

[51] G. Chen, M. Firth, Y. Xin, and L. Xu, "Control transfers, privatization, and corporate performance: efficiency gains in China's listed companies," Journal of Financial and Quantitative Analysis, vol. 43, no. 1, pp. 161-190, 2008.

[52] Q. Wang, T. J. Wong, and L. Xia, "State ownership, the institutional environment, and auditor choice: evidence from China," Journal of Accounting and Economics, vol. 46, no. 1, pp. 112-134, 2008.

[53] G. Q. Liu and D. Wang, "How does government accounting supervision affect earnings management," Journal of Management World, vol. 5, pp. 157-171, 2021.

[54] X. L. Wang, G. Fan, and G. R. Ma, China's Provincial Enterprise Business Environment Index 2017 Report, Social Science Literature Press, Beijing, China, 2017.

[55] M. C. Jensen and W. H. Meckling, "Theory of the firm: managerial behavior, agency costs and ownership structure," Journal of Financial Economics, vol. 3, no. 4, pp. 305-360, 1976.

[56] M. Dao, H.-W. Huang, and J. Zhu, "The effects of audit committee members' age and additional directorships on the cost of equity capital in the USA," European Accounting Review, vol. 22, no. 3, pp. 607-643, 2013.

[57] R. Xiang and W. C. Ni, "Gender diversity and accounting conservatism of audit committee: empirical evidence from Chinese listed companies," Investment Research, vol. 36, no. 1, pp. 23-37, 2017. 
[58] J. Li, J. Liang, V. Shi, and Q. Wang, "The benefit of manufacturer encroachment considering consumer's environmental awareness and product competition," Annals of Operations Research, vol. 3, pp. 1-19, 2021.

[59] J. Li, F. Wang, and Y. He, "Electric vehicle routing problem with battery swapping considering energy consumption and carbon emissions," Sustainability, vol. 12, no. 24, p. 10537, 2020.

[60] J. Li, L. Yi, V. Shi, and X. Chen, "Supplier encroachment strategy in the presence of retail strategic inventory: centralization or decentralization?” Omega, vol. 98, Article ID 102213, 2021.

[61] J. Li, Z. Hu, V. Shi, and Q. Wang, "Manufacturer's encroachment strategy with substitutable green products," International Journal of Production Economics, vol. 235, Article ID 108102, 2021. 